\title{
Faculty Loan Policies in Michigan, Ohio, and Indiana
}

\begin{abstract}
A survey was made to determine the circulation policies for faculty in the college and university libraries of Indiana, Michigan, and Ohio; to determine whether or not they seemed to be satisfactory; and to elicit suggestions on how faculty loan policies could be improved. The respondents were divided into two statistical groups according to size of enrollment-larger institutions (over 1,500) and smaller institutions (under 1,500). The survey revealed that increasing enrollments and expanding research functions on campuses are necessitating more efficient control of library materials which historically has been hampered by lax faculty circulation policies.
\end{abstract}

B ECAUSE OF THE DEARTH of professional literature concerning the many ramifications of academic library circulation policies, a study of faculty loan policies was initiated. The purpose of this survey was to determine what circulation policies existed for faculty in the college and university libraries of Indiana, Michigan, and Ohio; to determine whether the systems used seemed to be satisfactory; and to elicit suggestions on how they could be improved. The survey was based on all institutions of higher learning in the three states which appeared in the Education Directory 196566-Higher Education, and were listed as having North Central Association of Colleges and Secondary Schools accreditation. The total number of questionnaires sent was 128 . Of these, 105 were returned, which constituted 82 per cent of the total survey. Two returns were not complete enough to tabulate, so the

This survey was undertaken jointly with Mrs. Kathryn Blackwood. Mr. Netz is on the library staff at Dordt College, Sioux Center, Iowa. following tables are based on a total of 103 questionnaires. Fifty-six institutions requested copies of the results of the survey, indicating rather widespread interest in the problem of faculty circulation policies.

The questionnaire consisted entirely of open-ended questions which were designed to elicit answers based on individual opinions-there were no "right" or "wrong" answers. The questionnaire was similar in structure to one used in a 1963 nationwide random survey by Bobinski. ${ }^{1}{ }^{\circ}$

The respondents have been divided for statistical tabulation according to size of enrollment, which provided the most accessible criterion for common problems. ${ }^{2}$ The larger institutions were considered to be the fifty-nine schools with enrollments over one thousand five hundred. The smaller institutions were the forty-four schools with enrollments under one thousand five hundred. ${ }^{3}$ Also included in this group were all junior

- Footnotes are listed at the end of this article. 
colleges, regardless of size, because their lack of research facilities and less comprehensive academic programs tended to make their problems similar to those of the smaller institutions.

\section{Statistical Results ${ }^{4}$}

1. Is there a written policy statement in your library concerning faculty loan regulation?

\section{TABLE 1}

Percentage Having Written Policy Statements

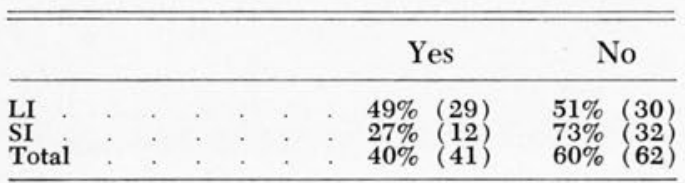

It should be pointed out that the majority of written policy statements were included in faculty manuals or university handbooks, rather than in formal, administrative policy statements of the library. Also, the large number of negative answers is quite surprising, since this apparently indicates that this important public relations operation is handled by word-of-mouth or on a commonunderstanding basis.

2. How long do books circulate to faculty members?

Although a majority ( 55 per cent) of the librarians indicated some type of specified loan period for faculty members, in many cases these loan periods were indefinite because of the lack of enforcement of faculty regulations. Therefore it appears that more than 65 per cent of the libraries have little or no control over the length of time that a faculty member may have library material in his possession.

3. What is the faculty loan policy and period for the following?

(This question concerned various types of special materials: e.g., periodical, reference, reserve, and microprint materials.) The results of this question varied greatly and tended to indicate that special materials were handled on an individualized basis, according to the needs of the particular institution.

4. Are faculty members subject to an overdue fine?

TABLE $4^{5}$

Percentage of Faculty Members Subject to Overdue Fines

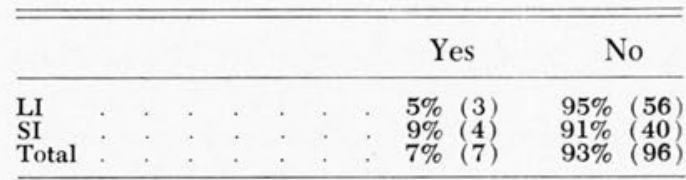

Concerning the imposition of fines upon faculty members, there seems to be almost unanimous agreement. Even the few libraries which did have fines for faculty members stated that these fines were of a theoretical nature, on special materials only, or seldom enforced. Many librarians, however, did indicate a desire to initiate a strict fine system for faculty violations of what the librarians viewed as liberal loan policies.

5. After what period of time is material recalled if wanted by another faculty member?

TABLE 2

Length of Faculty Circulation Period

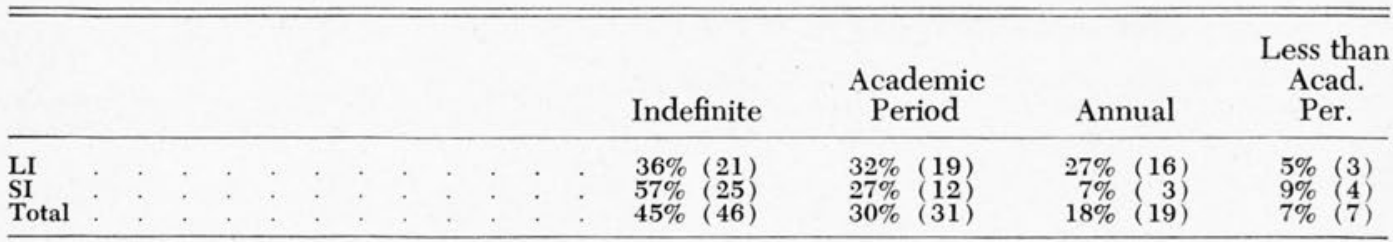


TABLE 5a

Recall Time for Material Wanted by Faculty

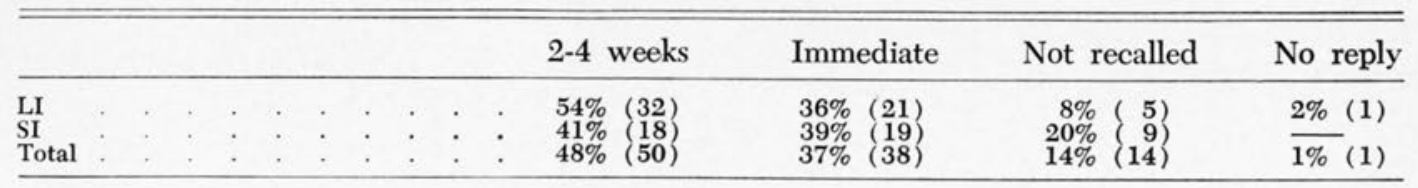

If wanted by a student?

TABLE $5 \mathrm{~b}$

Recall Time for Material Wanted by Students

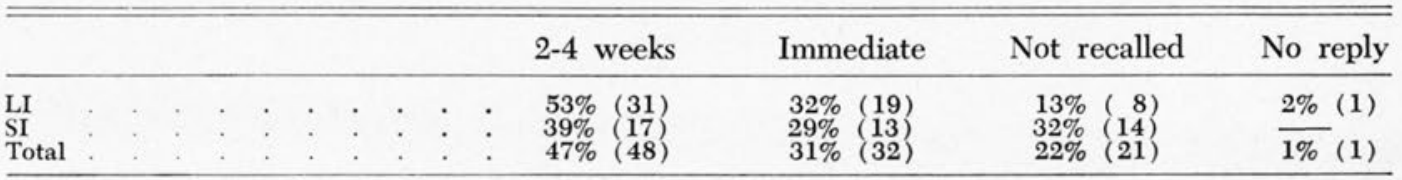

Eighty-one out of the 102 who replied stated that no differentiation was made in recalling materials for faculty or for students. In studying the responses, however, one can see that the existing recall services definitely favor the faculty. For instance, in the institutions which reported a policy of not recalling material 14 per cent would not do so for faculty while 22 per cent would not perform this service for students. In the smaller institutions such comments as "tough luck for the students" exemplified a prevalent attitude among the librarians. This can also be verified by the fact that 32 per cent of the smaller institutions did not have a material-recall service for the students. This factor of no recall coupled with the disparity of loan periods for faculty and students certainly indicates the element of student discrimination in existing circulation policies. Finally, a contributing fac- tor in the frustration caused by the existing recall procedures is the failure of the librarians to communicate effectively to the students the nature of their recall privileges.

6. What percentage of recalls do you estimate were returned within a reasonable time?

Even though the concept of "a reasonable time" was based on a subjective decision of each respondent, the majority of librarians indicated a high degree of faculty cooperation in the return of recalled materials. The larger institutions seemed to have greater problems in this area of recall, and those with the greatest problems were definitely the large universities, as indicated by the fact that in the case of the institutions reporting less than 75 per cent cooperation, all six of the "larger institutions" were in the large university category.

TABLE 6

Percentage of Recalls Returned within a Reasonable Time

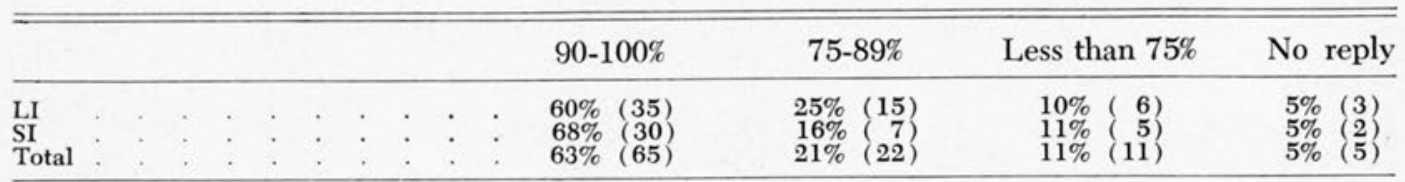


TABLE 7a

Initial Procedure to Retrieve Non-Returned Material from Faculty

\begin{tabular}{|c|c|c|c|c|c|c|c|c|c|c|c|}
\hline & & & & & & Written notice & Phone call & Personal & Other & , & No reply \\
\hline $\begin{array}{l}\text { LI } \\
\text { SI } \\
\text { Total }\end{array}$ & : & $\vdots$ & : & : & : & $\begin{array}{l}75 \%(44) \\
: \quad 64 \%(28) \\
\quad 70 \%(72)\end{array}$ & $\begin{array}{l}8 \% \\
2 \% \\
2 \% \\
6 \%\end{array}$ & $\begin{aligned} 3 \% & (2) \\
16 \% & (7) \\
9 \% & (9)\end{aligned}$ & $\begin{array}{l}12 \%\left(\begin{array}{l}7 \\
11 \% \\
11 \%(12)\end{array}\right) \\
12 \%(12)\end{array}$ & & $\begin{array}{l}2 \% \quad(1) \\
7 \% \\
4 \%\end{array}$ \\
\hline
\end{tabular}

TABLE $7 \mathrm{~b}$

Follow-up Procedure to Retrieve Non-returned Material from Faculty

\begin{tabular}{|c|c|c|c|c|c|c|c|}
\hline & Phone call & Personal & Written notice & Invoice & $\begin{array}{l}\text { Contact } \\
\text { superior }\end{array}$ & Other & No reply \\
\hline $\begin{array}{l}\text { LI } \\
\text { SI } \\
\text { Total }\end{array}$ & $\begin{array}{l}30 \% \\
16 \% \\
24 \%\end{array} \quad\left(\begin{array}{r}18 \\
25\end{array}\right)$ & $\begin{array}{l}20 \% \\
45 \% \\
31 \% \quad(20)\end{array}$ & $\begin{array}{r}12 \%\left(\begin{array}{r}7 \\
9 \% \\
11 \%\end{array}\left(\begin{array}{r}41 \\
11\end{array}\right)\right.\end{array}$ & $\begin{array}{l}9 \% \\
9 \% \\
5 \% \\
7 \% \\
7 \%\end{array}$ & $\begin{array}{ll}7 \% & (4) \\
7 \% & (3) \\
7 \% & (7)\end{array}$ & $\begin{array}{l}20 \%(12) \\
11 \% \\
16 \%(17)\end{array}$ & $\begin{array}{l}2 \%(1) \\
7 \% \\
4 \%(3)\end{array}$ \\
\hline
\end{tabular}

7. What procedure is used to retrieve library material not returned by faculty at the end of the specified loan period? (Initial contact)

After material has been recalled and not returned? (Second contact)

Written notices predominated ( 70 per cent) as the method of initial notification of non-returned material. Followup in the smaller libraries was usually done on a personal basis-either by phone or face-to-face. Although personal contact, including face-to-face confrontations and phone calls, was also used extensively ( 50 per cent) by the larger institutions for second contact, there was a trend ( 30 per cent) toward more disciplinary action among both groups. Some of the more stringent actions included the withholding of pay checks, and notification of department chairmen concerning the delinquency of the faculty members with library materials. A unique approach to this problem was the inclusion of accounts of faculty irresponsibility with library materials in the permanent records of the individual. This problem of material retrieval has by no means been effectively solved, however, as indicated by one librarian who expressed his procedures as
"We cry a lot," which seemed to express the sentiment of others.

8. Is there dissent or dissatisfaction voiced by the student body concerning your present faculty loan regulations?

TABLE 8

Student Dissent Concerning Faculty Loan Regulations

\begin{tabular}{|c|c|c|c|c|}
\hline & & Yes & No & No reply \\
\hline $\begin{array}{l}\text { LI } \\
\text { SI } \\
\text { Total }\end{array}$ & . & $\begin{array}{r}21 \%(12) \\
7 \% \\
15 \%(15)\end{array}$ & $\begin{array}{l}79 \%(47) \\
91 \%(40) \\
84 \%(87)\end{array}$ & $\begin{array}{l}\overline{2 \%}(1) \\
1 \%(1)\end{array}$ \\
\hline
\end{tabular}

Student dissent was significantly greater in the larger institutions (21 per cent as compared with 7 per cent for the smaller schools), especially in the universities where there were vocal graduate students. Complaints of discrimination in lending practices and faculty abuse of library privileges were often cited by the students. One institution in particular was in the midst of a major student protest against faculty abuses. These protests were expressed by means of student newspaper exposés and vehement editorials.

9. Are there complaints on the part of faculty members concerning loan regulations imposed upon them? 


\section{TABLE 9}

Faculty Complaints Concerning Loan Regulations

\begin{tabular}{lccc}
\hline & Yes & No & No reply \\
\hline LI & $24 \%\left(\begin{array}{r}14) \\
6\end{array}\right)$ & $73 \%(43)$ & $3 \%(2)$ \\
SI $\quad: \quad 14 \%(37)$ & $2 \%(1)$ \\
Total & $19 \%(20)$ & $78 \%(80)$ & $3 \%(3)$ \\
\hline
\end{tabular}

A greater percentage of the faculty of the larger schools ( 24 per cent) than the smaller schools (14 per cent) tended toward open criticism of their colleagues' abuse of library privileges and stated a desire for more effective faculty circulation regulations. On the other hand, some faculty members were personally affronted by the laborious task of checking library materials in their possession for annual inventories.

10. What changes, if any, have been made in your faculty circulation policies during the last few years?

TABLE 10

Changes in Faculty Circulation Policies

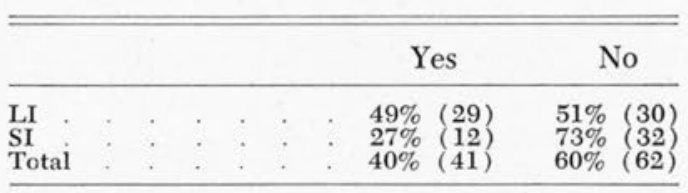

The comments included with this question indicated that there have been recent attempts to revise faculty circulation policies. A much greater proportion of the changes in the larger institutions (49 per cent versus 27 per cent) seems to indicate a more pressing need for coping with increasing enrollments and growing demands upon all library facilities. The trend of these changes is definitely toward greater control of materials. This trend has manifested itself in limited loan periods, periodic library inventories, exclusion of faculty families from extended privileges, and stricter enforcement of library regulations concerned with faculty loan privileges. Only five of the forty-one librarians (12 per cent) who reported changes in faculty circulation policies stated that the change was toward liberalization of regulations.

11. Are you, as librarian, satisfied with your present policies concerning faculty loans?

TABLE 11

Librarians Satisfied with Present Faculty LOAN POLICIES

\begin{tabular}{|c|c|c|c|c|c|c|c|}
\hline & & & & & & Yes & No \\
\hline $\begin{array}{l}\text { LI } \\
\text { SI } \\
\text { Total }\end{array}$ & : & : & : & : & . & $\begin{array}{l}61 \%(36) \\
: \quad 86 \%(38) \\
: \quad 72 \%(74)\end{array}$ & $\begin{array}{l}39 \% \quad(23) \\
14 \% \quad 6 \\
28 \% \quad(29)\end{array}$ \\
\hline
\end{tabular}

Librarians in smaller institutions seem to have significantly fewer problems with faculty circulation than those in the larger schools. Most were satisfied with their present circumstances concerning faculty loans ( 86 per cent) and attributed this to the small number of faculty members with whom they had frequent personal contact. Most of the problems which were mentioned at smaller institutions concerned the abuse of library privileges by a small minority within the faculty. Within the larger institutions, however, there was a greater expression of dissatisfaction by the librarians. This dissatisfaction was strongly expressed by one librarian at a large university:

No, I am not satisfied. No distinction should be made between faculty and students. The same loan privileges should be accorded to all persons eligible to use the academic library. The insistence of the professoriate that they are a race apart is a relic of the Middle Ages. The sequestration of library materials for long periods of time in faculty offices or homes is intolerable. Furthermore, such permissiveness works against them quite as much as it works against students. Academic libraries must be able to control their collections, for only with control can they satisfy the entire university community.

Although the preceding statement is 
more verbose than the average response, in reviewing the results of the survey it is apparent that the population explosion on college campuses and the expanding research functions of the college and university library are necessitating more efficient control of materials in order to meet the demands of scholarship by all library users. Faculty censure by administrative action in cases of habitual abuse of library privileges, stricter overdue and recall policies, establishment of unilateral circulation policies for all members of the academic community, and the desire for other forms of stricter control of library materials were cited as means of increasing library service for all academic library patrons.

There seems to be a general lack of control in the existing faculty circulation policies, as shown by ineffective recall procedures and unlimited loan periods for faculty. There is a growing awareness by librarians that the availability of library materials must be assured for every member of the academic community. From the various responses of the librarians it seems that the smaller libraries have not yet felt the researchoriented taxing of library resources, and thus the librarians of smaller institutions limit their criticism of circulation prob- lems to a minority abuse by faculty, rather than to the entire system of faculty privilege. On the other hand, many large university libraries are facing varying stages of crisis in their attempts to maintain good public relations with all segments of the academic population, a result of the unrealistic concept of noncontrolled circulation of library materials by faculty members. Currently there is no universal circulation policy for all the academic libraries of this country. Therefore, constant awareness of the changing needs of the academic community must dictate the library circulation policies for each institution, and every policy must assure the availability of the library's resources to all patrons.

\section{NOTES}

${ }^{1}$ George S. Bobinski, "Survey of Faculty Loan Policies," College \& Research Libraries, XXIV (November 1963), 483-86.

${ }^{2} \mathrm{~A}$ second alternative would have been to divide the respondents by the size of their library holdings. However, this information was not available at the time that the results of this survey were tabulated.

${ }^{3}$ Although the enrollment of 1,500 was an arbitrary choice as the dividing point between the two size groups, the writer defends its validity on the basis that it presents a representative picture of the similarity of distribution between the sample ( 103 institutions) and the universe (128 institutions).

${ }_{4}^{4}$ Results are in terms of percentage for each category. Number in parentheses represents total responses for each cell. $\mathbf{L I}=$ Larger Institutions. $\mathrm{SI}=$ Smaller Institutions.

${ }^{5}$ There is no Table III, due to non-tabulation of question 3.

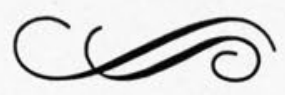

